\title{
Mammoths used as food and building resources by Neanderthals: Zooarchaeological study applied to layer 4, Molodova I (Ukraine)
}

\author{
Laëtitia Demay*, Stéphane Péan, Marylène Patou-Mathis \\ Muséum National d'Histoire Naturelle, 1, rue René Panhard, 75013 Paris, France
}

\section{A R T I C L E I N F O}

Article history:

Available online 27 November 2011

\begin{abstract}
A B S T R A C T
Considering Neanderthal subsistence, the use of mammoth resources has been particularly discussed. Apart from procurement for food, the use of mammoth bones as building material has been proposed. The hypothesis was based on the discovery made in Molodova I, Ukraine (Dniester valley). In this large multistratified open-air site, a rich Mousterian layer was excavated. Dated to the Inter-Pleniglacial (MIS 3), it has yielded 40000 lithic remains associated with ca. 3000 mammal bones, mostly from mammoth. Several areas have been excavated: a pit filled with bones, different areas of activities (butchering, tool production), twenty-five hearths and a circular accumulation made of mammoth bones, described as a dwelling structure set up by Neanderthals. Attested dwelling structures made of mammoth bones are known in Upper Paleolithic sites, from Ukraine and Russia, attributed to the Epigravettian tradition.

This paper presents a zooarchaeological study of large mammal remains from Molodova I layer 4, to understand the modalities of acquisition and utilization of mammoth resources for food and technical purposes, especially to test the hypothesis of using bones as building elements. The number of mammoths is estimated to at least fifteen individuals of all age classes and both sexes, which died during several episodes, near or on the site.

The taphonomic modifications due to weathering, water percolation and plant roots indicate the location of bones in holes, such as the pit and the basement of the circular accumulation. Secondary actions of carnivores, especially of hyaenid type, are rare on bones, showing that the assemblage was not accumulated by these predators. The anatomical preservation, the age and sex features and the taphonomic data indicate several modalities of mammoth acquisition by hunting, scavenging and collecting.

Based on anthropogenic marks, mammoth meat has been eaten. The presence of series of striations and ochre on mammoth bones are associated with a technical or symbolic use. Furthermore, mammoth bones have been deliberately selected (long and flat bones, tusks, connected vertebrae) and circularly arranged. This mammoth bone structure could be described as the basement of a wooden cover or as a wind-screen. The inner presence of fifteen hearths, lithic artifacts and waste of mammal butchery and cooking is characteristic of a domestic area, which was probably the centre of a residential camp recurrently settled. It appears that Neanderthals were the oldest known humans who used mammoth bones to build a dwelling structure.
\end{abstract}

(c) 2011 Elsevier Ltd and INQUA. All rights reserved.

\section{Introduction}

The reconstruction of Paleolithic subsistence is one of the main objectives in studying archaeological records, in particular through zooarchaeology. In a general way, these studies deal with new data on relationships between mammoths and humans, and provide more information about Neanderthal subsistence strategies. The aim

\footnotetext{
* Corresponding author.

E-mail address: l.demaymnhn@hotmail.fr (L. Demay).
}

of this paper is to explore the zooarchaeological evidence from the Middle Paleolithic layer 4 of the Molodova I site (Ukraine). This site provoked a debate concerning the interpretation of a circular mammoth bone accumulation, described as a construction set up by Neanderthals during the Middle Paleolithic (Kernd'l, 1963; Chernysh, 1983). This would be the oldest use of mammoth bones as building material. The only attested mammoth bone dwelling structures have been associated to the Upper Paleolithic and Homo sapiens in the middle Dniepr basin, including the Desna valley, and the Don basin (Rogatchev, 1957; Shovkopljas, 1965; Pidoplichko, 1969, 1976, 1998). In order to shed new light on this debate, detailed zooarchaeological 


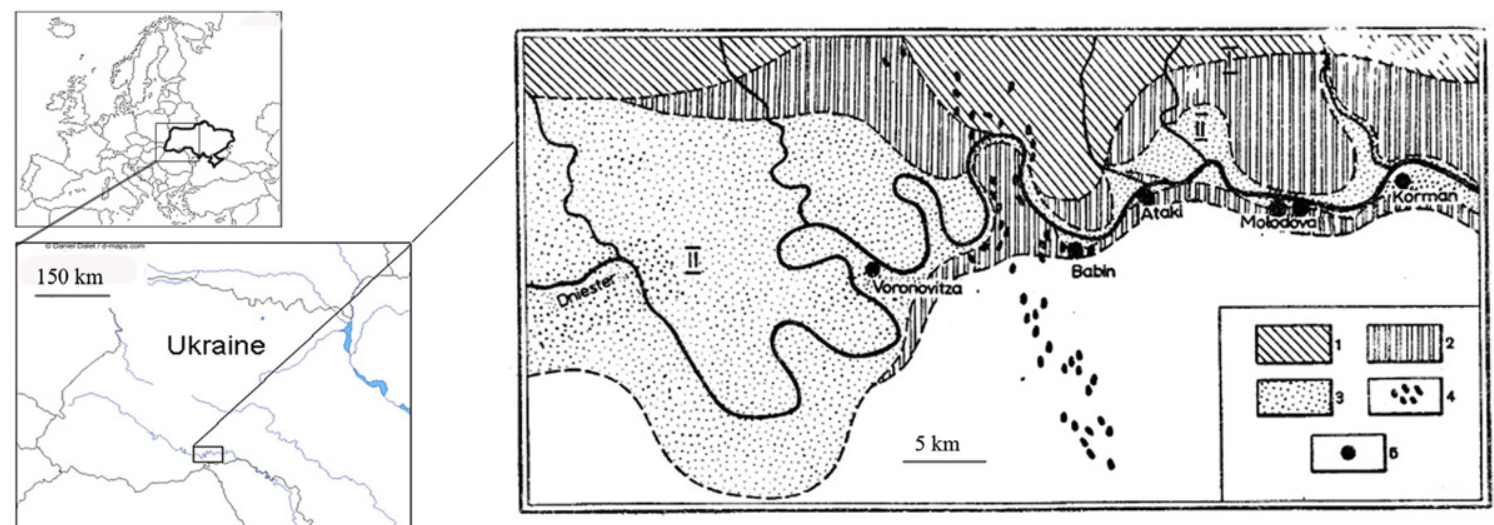

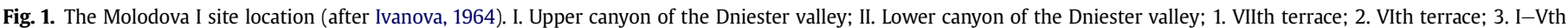
terrace; 4. Calcareous hills; 5. Paleolithic sites.

analyses have been carried out on the large mammal assemblage from Molodova I layer 4, which is dominated by mammoth remains. This is the first zooarchaeological study on this material. First, an effort was made to determine the modalities of human acquisition of the animals. Second, the modes of their utilization were identified. These objectives were accomplished through analysis of the faunal remains in relation with the spatial distribution of the bones and artifacts in layer 4 . Special attention was given to the circular mammoth bone accumulation. The aim was to test the hypothesis of a non-food use of mammoth resources by Neanderthals, especially as building materials.

\section{Context}

Molodova I isa Mousterian settlement located in the region of Chernivtsi, Ukraine.between the Dniester and the Carpathians (Figs. 1 and 2). This site is one of few deposits where the spatial distribution of bones was recorded in the field by plans and pictures.

\subsection{Historical background}

Molodova I was discovered in 1928 by I. G. Botez. The first excavations were carried on by I. G. Botez and N. N. Moroşan in 1931 and 1932, who identified several layers attributed to Mousterian and Upper Paleolithic settlements (Moroşan, 1929, 1931, 1938; Botez, 1930, 1933). A. P. Chernysh started excavations of Molodova I layer 4 in 1955 in the southwest part of the site. The center and the northeast area were excavated during the two next decades and from 1982 to 1984. From 1955 to 1982, A.P. Chernysh, G.I. Goretsky and I.K. Ivanova did considerable work to excavate and study nine cultural layers (Ivanova, 1958; Chernysh, 1982; Goretsky and Ivanova, 1982), in particular the Mousterian layer 4.

\subsection{Regional setting and geomorphology}

Layer 4 is situated in loessic deposits, indicating a dry and cold climate. The artifacts and bones of the Mousterian layers above were disturbed by solifluction and cryoturbation effects which indicate the development of permafrost, caused by a more humid and cold climate. These upper loessic deposits allowed good preservation of the artifacts of layer 4 .

\subsection{Chronostratigraphy}

The Molodova I site is composed of five Middle Paleolithic layers (numbered from 1 to 5 from the top to the bottom), three Upper Paleolithic layers and one Mesolithic layer. The Mousterian layer 4, $9.5 \mathrm{~m}$ deep (Fig. 3), is the richest one in term of lithic and bone remains. It is a maximum of $20 \mathrm{~cm}$ thick, in fine-grained sandy sediments with clay lenses. Dating of a charcoal recovered in a hearth gave an age older than $44000 \mathrm{BP}$ (GrN. 3659) (Chernysh, 1982). The microfauna, the malacofauna and the palynological data connect the layer 4 occupation with MIS 3 (Early Interpleniglacial) (Ivanova, 1982).

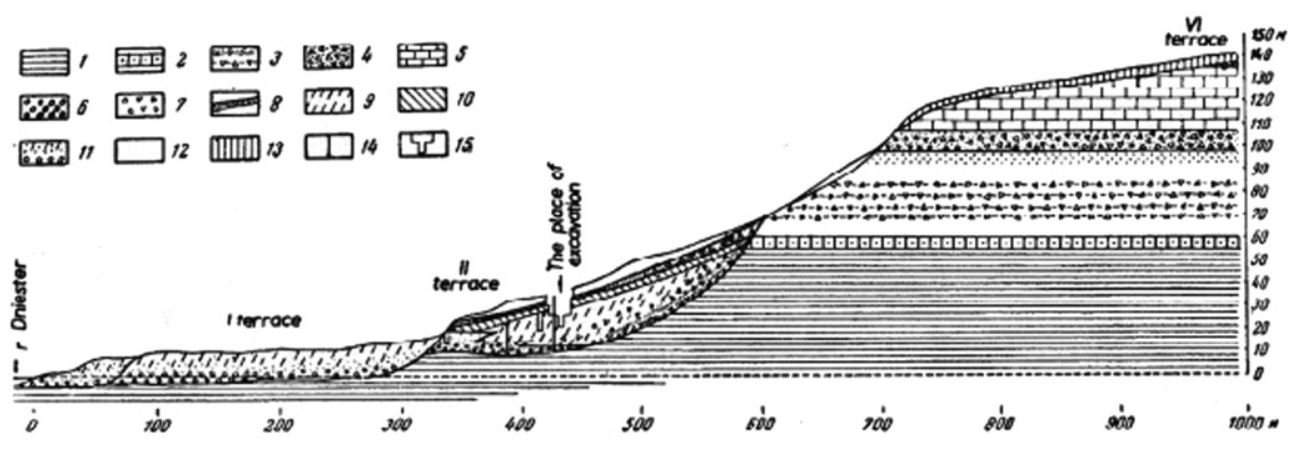

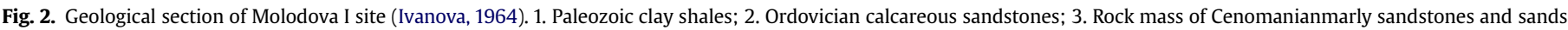

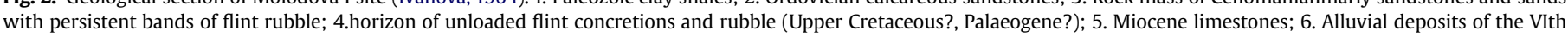

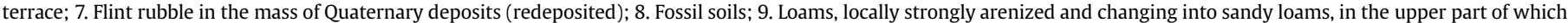

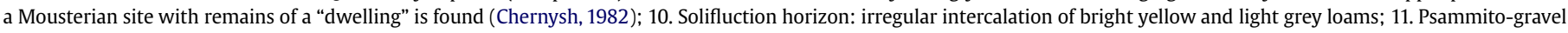

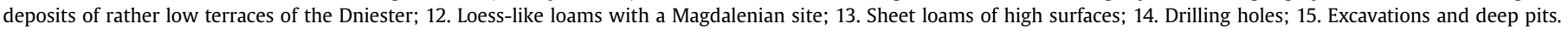




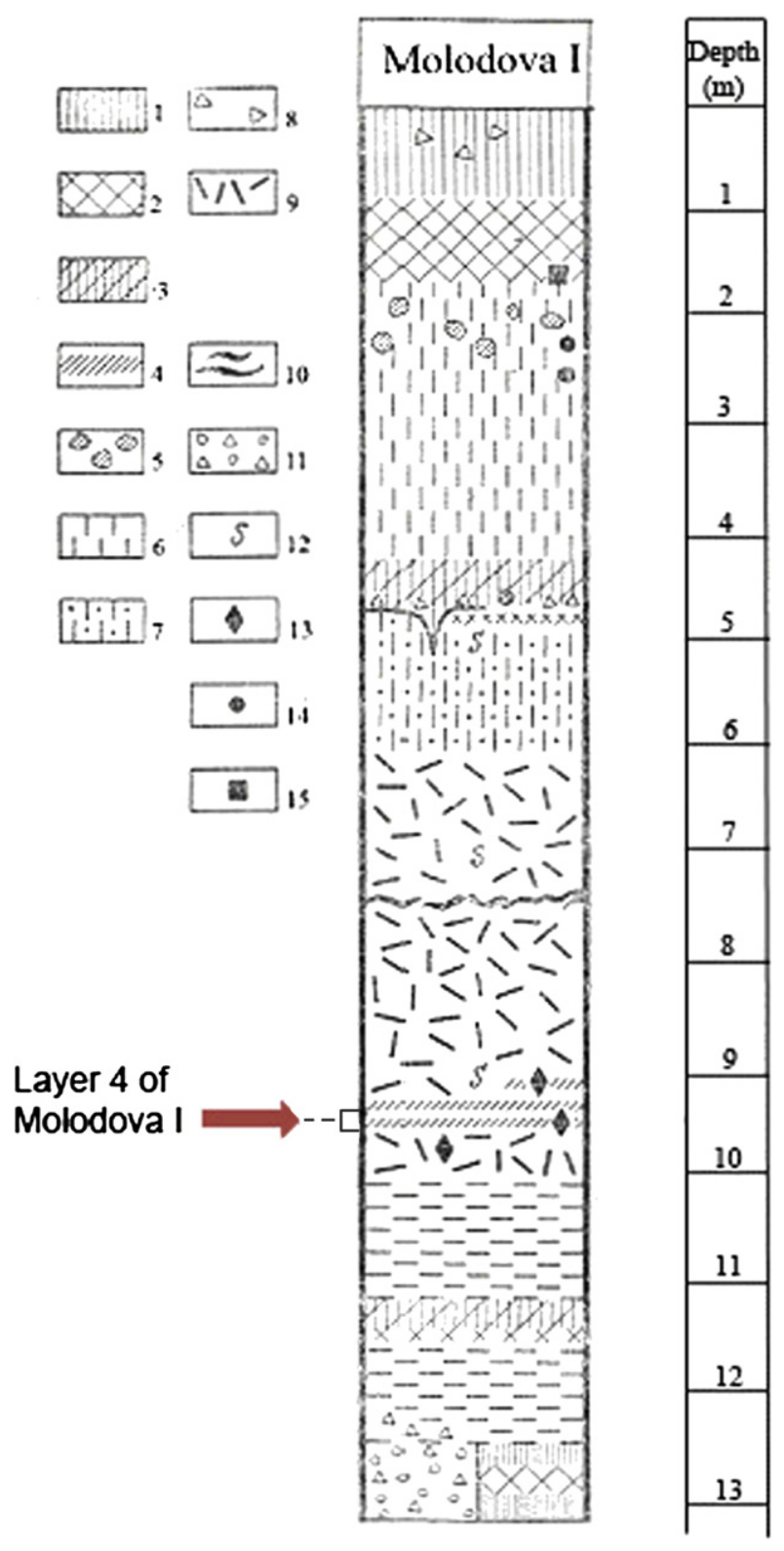

Fig. 3. Stratigraphy of Molodova I (after Ivanova, 1982, p.234). 1. Humus; 2. Brown clay; 3. Grey-brown dark clay; 4. Lens of clay; 5. Molehill; 6. Light clay; 7. Sandy clay; 8 . Raw flint; 9 . Scattered soil; 10 . Traces of charcoal; 11 . Alluvium; 12 . Traces of solifluction and cryoturbation; 13. Mousterian; 14. Upper Paleolithic; 15. Early Mesolithic.

\subsection{Lithic assemblage}

Among the five Mousterian layers, the artifacts from the fourth one are the most representative of the site. The inventory consists of 40000 flint artifacts, in particular 1327 nuclei and 7193 tools, which are characteristic typical Mousterian without bifacial form, with rare Quina elements (Chernysh, 1965, 1982). Tools are composed of blades with marginal retouches, retouched side-scrapers, and retouched Levallois flakes. The Dniester river terrace abounds with flint deposits. Those flint deposits were exploited as main raw material by a human group to make tools.

Microscopic observations have shown that lithic artifacts were used as projectile weapons to hunt game. They were also used as tools to process wood and butcher animals (Chernysh, 1982).

\subsection{Archaeological structures}

Layer 4 covers $1200 \mathrm{~m}^{2}$ and is composed of 5 areas (Fig. 4):

- a pit filled with bones without lithic artifacts;

- an area with bones which bear non-food human marks, such as parallel striations and ochre, named the "symbolic" area by Chernysh (1982);

- two areas at the east and west with accumulations of lithic flakes and bones; and

- a circular accumulation of bones with tools in its center.

This bone accumulation was interpreted in different ways. Chernysh $(1960,1982,1983,1989)$ described a Mousterian dwelling structure. Binford (1983) rejected the dwelling structure interpretation but kept the anthropic significance by interpretating a hunting blind. Klein (1989) wrote about an anthropic structure, but eventually considered it as a natural accumulation (Klein, 1999). Stringer and Gamble (1993) interpreted that the ring bones of Molodova I were not a habitation but a circular symbolic ring bound to Neanderthal beliefs. Kolen (1999) proposed that humans recurrently settled and pushed away garbage; this would have formed a ring of bones used as a base structure, which he named a "centrifugal living structure". Hoffecker (2002) suggested the hypothesis of a wind break for a long term occupation.

The excavations yielded 26 hearths from different sizes, from $40 \times 30$ to $100 \times 40 \mathrm{~cm}$ wide, and ashy lenses from 1 to $2 \mathrm{~cm}$ thick. Lithic artifacts and bone remains, notably from mammoth, were found in association with these hearths and ashy layers. Chernysh (1982) described marks of combustion on small bones of large mammals associated with hearths. According to Chernysh (1982), the layer could extend to the east and northeast beyond the excavated area.

\section{Material and methods}

The faunal material reported in this study consists of large mammal remains from Molodova I layer 4, curated in the National Museum of Natural History in Kiev (labels refer to 1961) and in the Museum of Archaeology in Lviv (labels refer to 1976-1980 and 1982-1984). More than half the bones (55\% of the total number of remains) bear indications of spatial distribution. They come from different areas of the site, excavated between 1955 and 1980 (Figs. 5-8). Not all the bones which are indicated on the published field plans were found in the collections (Fig. 4). Study included 2438 bone remains, whereas the published number of mammal remains was estimated at 3000 bones (Agadzhanian, 1982). If this amount equals the total number of excavated bones remains, only $19 \%$ of them would then be missing. Furthermore, it is probable that the smallest indeterminate pieces were probably not kept after the fieldwork (Nowell and d'Errico, 2007).

Except for paleontological descriptions and paleoecological studies (Vangengeïm, 1961; Ivanova, 1982), no zooarchaeological analyses of the large mammal remains had been previously done. The methods used in this study are those generally applied in zooarchaeology (Patou-Mathis, 1994). The material was anatomically and taxonomically determined. Mammoth individual ages were established from tooth development stages and bone measurements (Haynes, 1991). This information allows the establishment of an age profile of the population. Sex determination was made from osteometric references (Lister, 1996). Paleoenvironmental reconstitution was obtained from ecologic diagrams and faunal associations (Faure and Guérin, 1984). Taphonomic studies are useful to identify bone surface modifications and their responsible agents, in particular 


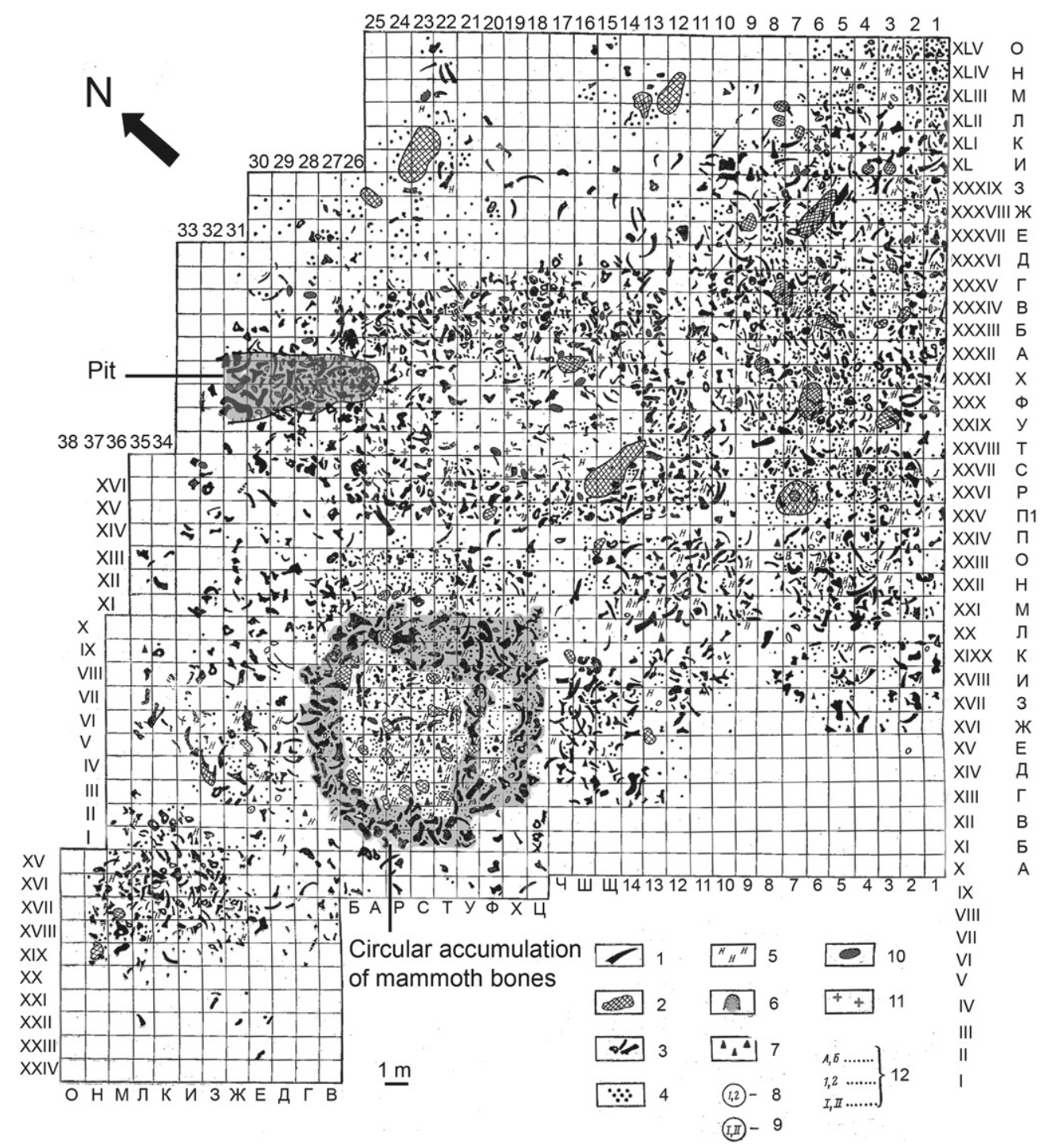

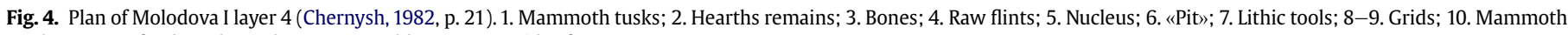
teeth; 11. Non-food marks on large mammal bones; 12 . Grid references.

humans. The spatial distribution of artifacts and bones was useful to understand the use of mammoth resources.

\section{Results}

\subsection{Paleontonlogy}

The studied faunal assemblage of Molodova I layer 4 is composed of 2438 remains (Table 1 ). The faunal spectrum composition by taxonomic orders shows that Proboscideans are predominant. However, Artiodactyls represent the most diversified group.

The herbivorous species are Mammuthus primigenius (woolly mammoth), Cervus elaphus (red deer), Bison priscus(steppe bison), Rangifer tarandus (reindeer), Equus sp.(horse of caballine type) and Coelodonta antiquitatis (woolly rhinoceros). Carnivores are represented by Vulpesvulpes/Alopex lagopus (red fox/polar fox), Canis lupus (wolf) and Pantherapardus (panther).

According to Ivanova (1982), the horse remains are attributed to Equus latipes and Equus latipes gromonova. This subspecies is not presently attested (Eisenmann, 2010), but two pieces (one metapodial and one femur) could belong to a rather small adult horse=
This small individual could correspond to the controversial subspecies indicated by Ivanova.

The studied mammoth bones are located mainly in and around the pit ( $86 \%$ of the total number of mammoth remains; $17.6 \%$ of the minimum number of elements), in the circular accumulation $(5.2 \%$ of the total number of mammoth remains; $7.4 \%$ of the minimum number of elements), and to a lesser extent in the east (5.9\% of the total number of mammoth remains) and southwest (2.4\% of the total number of mammoth remains) areas of the site (Figs. 5-7). The bones of bison, reindeer, red deer, wolf and woolly rhinoceros are mainly located in the pit and the circular accumulation. The horse remains are located in the southeast area (Fig. 8).

\subsection{Paleoecology}

Paleoecological information was based on the faunal spectrum. Cervus elaphus is a taxon which usually lives in rather humid forest areas. Its presence would indicate the development of sporadic forests. It is associated with taxons which evolved in dry cold open areas, such as Rangifer tarandus, Bison priscus, Coelodonta antiquitatis and Mammuthus primigenius. The carnivores Alopex 


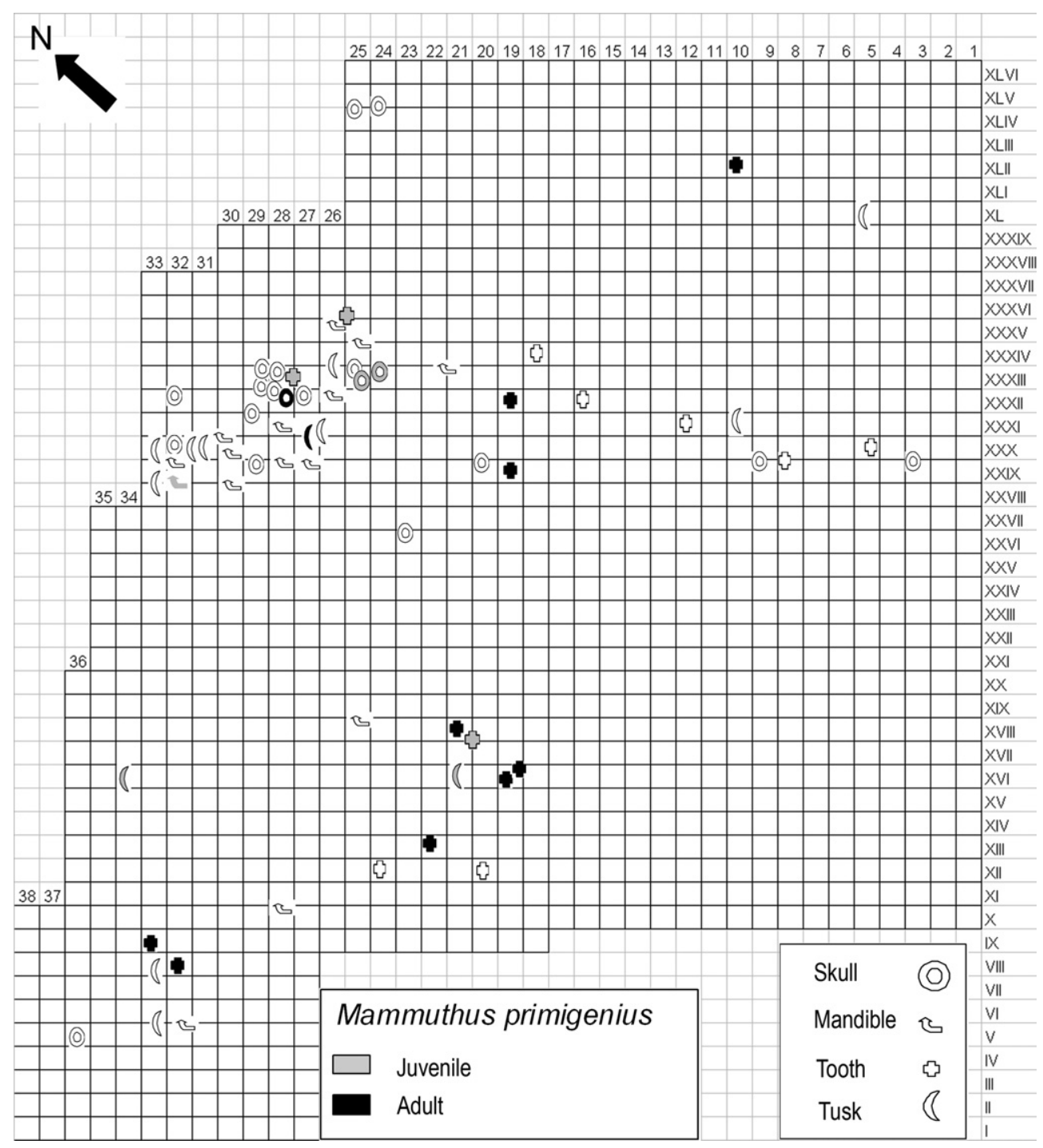

Fig. 5. Spatial distribution of the skull remains of mammoth from Molodova I layer 4.

lagopus/Vulpes vulpes, Panthera pardus and Canis lupus can live in open or closed environments. Their association with large mammals describes a wide open plain area with coniferous forests along the river. The climate was dry and cold.

The rodents and insectivores are represented by Marmota bobac (marmot), Clethrionomys sp. (vole), Microtus hyperboreus (siberian vole), Microtus gregalis (head-pointed vole), Microtus agrestis (rustic vole), Microtus sp. (vole), Lagurus lagurus (steppe lemming), Lagurus sp. (lemming), Dicrostonyx sp. (collared lemming), Dicrostonyx henseli (extinct lemming), and Lemmus sp. (striped lemming) (Agadzhanian, 1982). The presence of these rodents confirms the juxtaposition of cold open plain, bush and forest species. The taxon $M$. bobac is related to a steppe landscape. D. henseli, a rodent which lived during Quaternary cold periods and disappeared during the Holocene, confirms that the rodent assemblage age was formed during the Pleistocene (Bouchud, 1952).

\subsection{Skeletal preservation of mammoth}

Most of the mammoth remains from Molodova I layer 4 are wellpreserved. The percentage of survival indicates a good preservation of flat bones, followed by skulls, mandibles, tusks, cervical and lumbar vertebras (Fig. 9). Long bones are unequally represented.
Limb extremities are the less represented parts, except for the larger elements such as the talus. The axial skeleton is the most fragmented part. The morphology and the bone structure of the small anatomical elements are conducive to their alteration and destruction.

All skeletal elements are represented, except the caudal vertebras, even short bones. Left and right parts of the skeleton are equally represented (Table 2 ). These data indicate that mammoths died near or at the site.

The mammoth bones are mostly located in the pit and in the circular accumulation. In the pit, all element types are present, but ribs are predominant. The circular accumulation is mainly composed of complete elements which include flat bones (scapulas, innominates, skulls), long bones (humerus, radius, ulna, femurs, tibias, fibulas), tusks and anatomic group(s) of vertebras (Table 4).

\subsection{Structure of the mammoth population}

Considering tooth eruption and wearing stages, at least fourteen individuals were identified, from juveniles to mature adults. A fifteenth mammoth was an older individual according to an arthrosic feature present on two bones (a radius and a fibula), confirmed by a high epiphysation stage on a rib and a tibia. All age classes are represented, with a predominance of young and mature adults. 


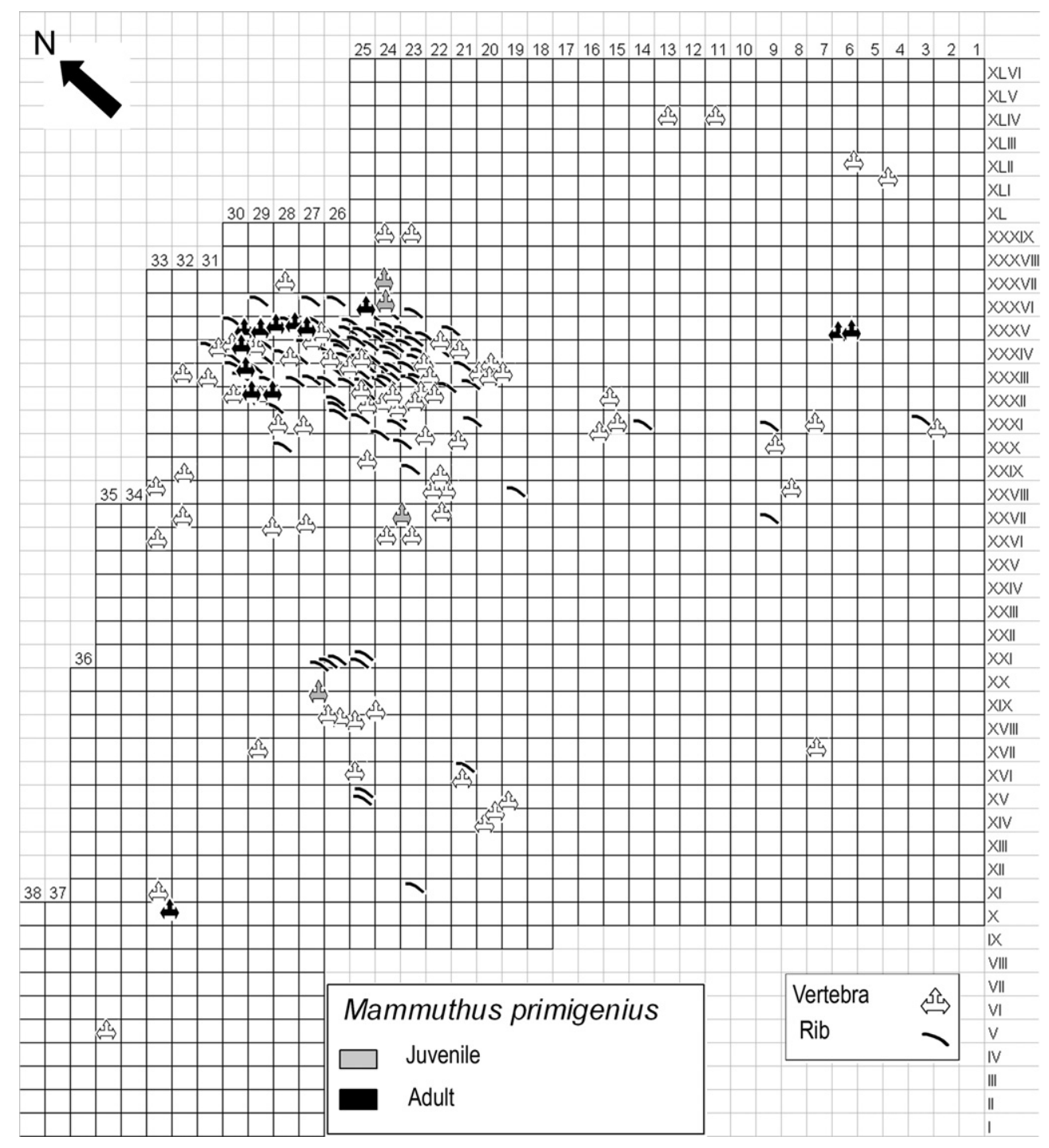

Fig. 6. Spatial distribution of the axial skeleton remains of mammoth from Molodova I layer 4.

Based on the measurements of eight innominates and twelve proximal parts of tusks, it seems that only two adult males are present, whereas most of the individuals are juveniles or female adults (Fig. 10). Furthermore, one rather small radius exhibits fused proximal and distal ends, attributed to a female adult.

The mortality curve obtained does not look like a typical death profile (Fig. 11). In a typical mortality curve, mammoths are mostly juveniles. It usually shows a decreasing representation of the other age classes. Mammoths hunted by humans belong to a selected development stage, such as juveniles or young adults, mainly females (Haynes, 1991). The mammoth assemblage from Molodova I layer 4 seems to result from both natural death and hunting, through several episodes of death. Predators such as humans hunted them. The spatial distribution of mammoth bones according to age and sex exhibits an equal representation in all areas of the site.

\subsection{Taphonomy}

\subsubsection{Climato-edaphic factors}

Open-air sites are generally less altered by post-depositional processes than are caves. The Molodova I site is located in the middle of the external bank of a fluvial terrace, an area generally favourable to bone preservation. Loessic sediments have a low porosity which minimizes water percolation, damage, and movement of bones. These sedimentary features explain the good preservation of the bone material from Molodova I layer 4.

The main modifications due to water infiltration are hydrolysis, oxidation, and dissolution. Oxidation of iron and manganese leaves respectively red and black colouration on bones, especially those which stay in depressions. All bone types (flat, long and short bones) from Molodova I layer 4 bear oxide colors (26.5\% of remains), in particular long bones and ribs, from all species except the horse. Bones of woolly rhinoceros are more coloured than the other large mammals. They are situated in the pit and the circular accumulation (Table 3 ). Oxide coloration is often associated with dissolution ( $1.7 \%$ of remains).

Despite several comminuted bones, the assemblage was not notably affected by mineral and organic acids. One vertebra spine of mammoth shows a perpendicular fracture and longitudinal cracking. This kind of breakage is due to the alternation of desiccation and hydration rather than to the sediment weight action.

Compaction marks are present on two innominates, two ribs, one long bone and several vertebrae in the pit. Inside the pit, the bone fractures could be the result from the stacking weight.

Weathering slightly modified all bone types of the assemblage ( $10.8 \%$ of remains), especially the flat bones. It is more intense in the 


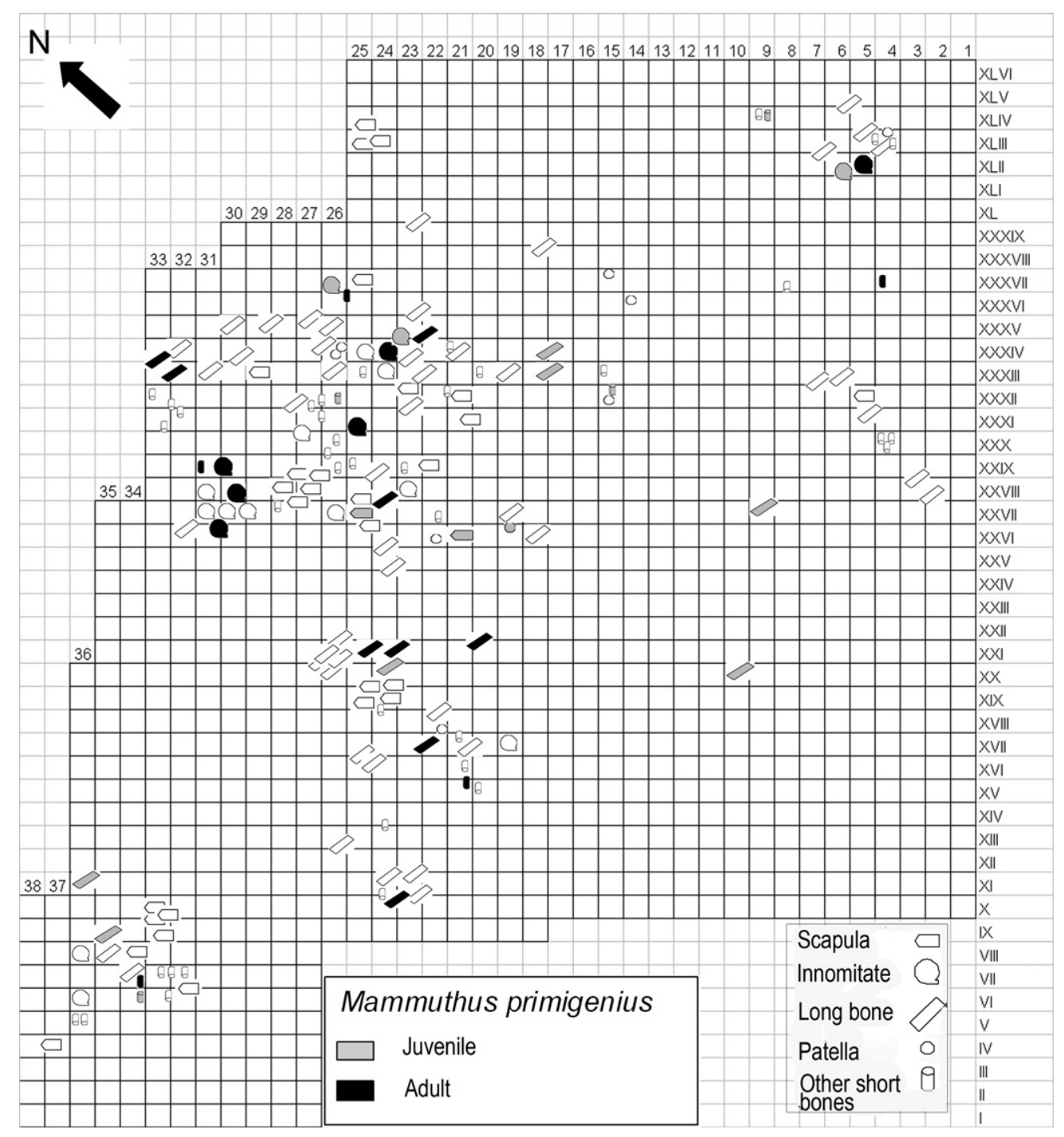

Fig. 7. Spatial distribution of the limb bones of mammoth from Molodova I layer 4.

pit and the circular accumulation. Bones of woolly rhinoceros are particularly more weathered. The reduced weathering of the material is characteristic of limited exposure to fresh air (Behrensmeyer, 1978). The faunal assemblage from layer 4 was quickly buried, except for the material from the pit and the circular accumulation. Woolly rhinoceros bones exhibit emphasized modifications by climato-edaphic factors compared to the other mammals. This difference of preservation indicates at least two episodes of accumulation of the assemblage.

\subsubsection{Plants}

Plant roots can leave post-burial marks on bones. The clay lenses of layer 4 were probably favourable to plant growth. In layer 4 , all bone types from all species bear rootlet prints (7.2\% of remains). Bone remains which are affected by plant root marks are generally those which are modified by weathering. They are concentrated in the pit and in the circular bone accumulation. Therefore, these bones stayed a long time in the subsurface before they were finally buried.

\subsubsection{Carnivores and rodents}

One mammoth rib bears rodent marks. Except for two reindeer bones, mammoth is the most represented taxon which was damaged by Canids and Hyaenids (41 remains, 3.4\% of mammoth NISP). The low representation of carnivore actions on bones shows that they are the origin of the mammoth bone accumulation.

Carnivores gnawed long bone epiphyses, scapula glenoidal cavities and metapodials from mammoth of all ages. Also, several fragments show fractures made by carnivores. Most carnivore modifications are typical of the Hyaenids. Bones gnawed by carnivores never bear any human marks. They are located in the pit filling, in the bottom part.

Mammoth bones may have been modified by carnivores when they were still in fresh carcasses out of the site, before they were carried to the pit. Conversely, carnivores may have gnawed bones in the pit after their deposition by humans. The co-occurrence of bones modified by human butchery (see below) and others modified by carnivore gnawing in the same pit filling could result from the alternation of human settlements and carnivore activities.

\subsubsection{Trampling}

Bones trampled by humans and animals can be broken and can bear striations. Bone flakes in Molodova I layer 4 are mainly $5-20 \mathrm{~cm}$ long, indicating that the faunal material was not intensively trampled. 


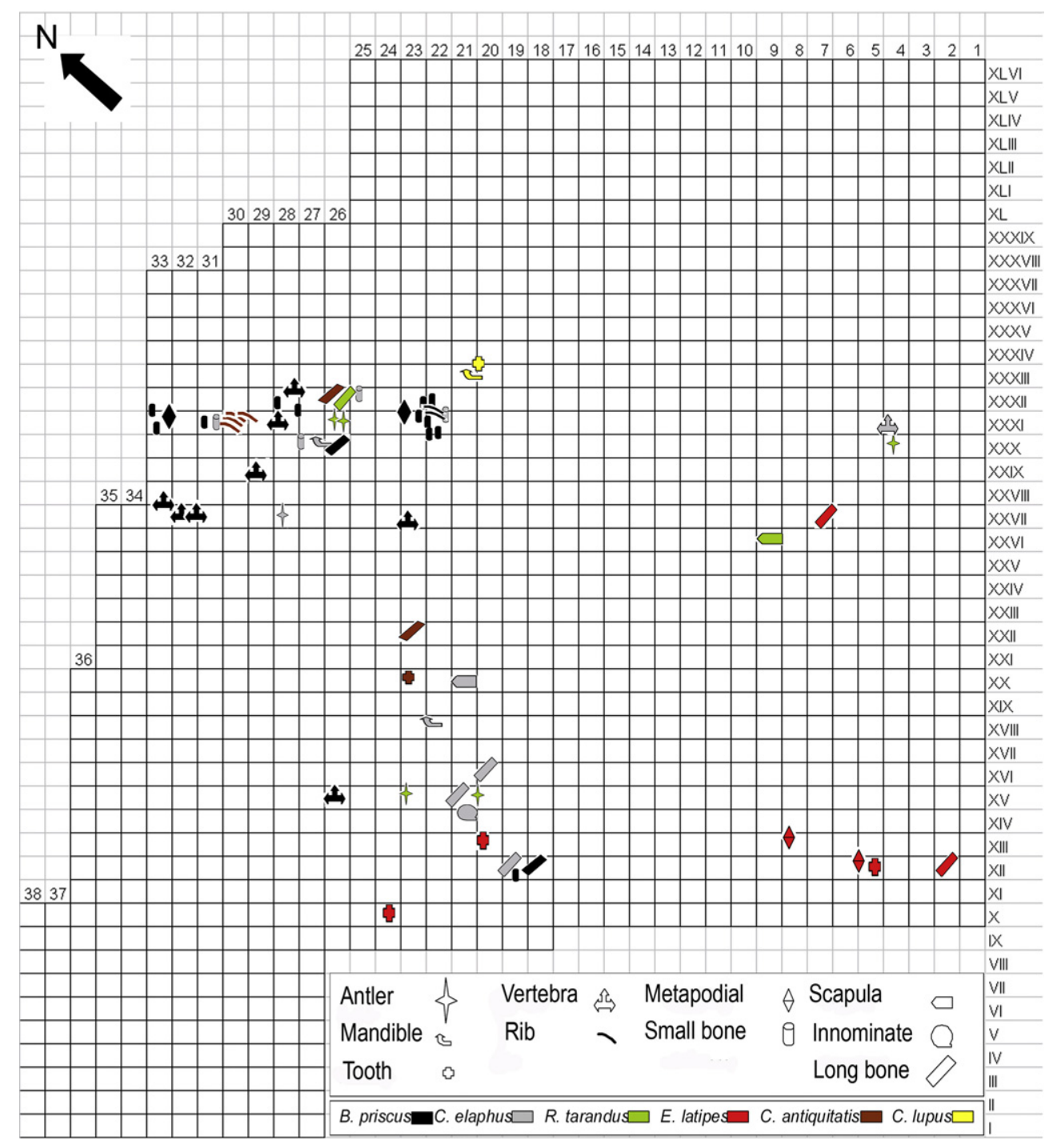

Fig. 8. Spatial distribution of the faunal remains different from the mammoth from Molodova I layer 4.

However, most of the small flakes were probably not kept during the original fieldwork. Trampling marks are present on three rib fragments and three long bones of mammoth from the pit, its periphery or inside the circular bone accumulation. Goretsky and Ivanova (1982) described trampled herbivore short bones in the bone accumulation. The trampling modifications noticed in the surfaces of the bones of the pit periphery and inside the circular bone accumulation could be explained by the repetitive walking of humans.

\subsection{Human-made taphonomic modifications}

Marks left by humans on bones result from both food and non-food related activities.

\subsubsection{Food-related modifications}

Different butchering marks were observed on bison bones: cutmarks on three thoracic vertebrae, one rib, two tibias on lateral and anterior sides, and two metapodials and green bone fracturation on a radius and a metapodial. One reindeer tibia and one red deer radius bear spiral fractures. Short bones are often associated with hearths, probably to prepare stock. One shows a combustion mark. These three species have been hunted and eaten by humans.
Concerning the mammoth, one projectile impact and probably another one were observed on two ribs, probably engendered by a hunting weapon.

Striations due to cutting process are exhibited on three zygomatic bones, one cervical vertebra, nineteen fragments of rib body (on both sides), three innominates, one femur, six long bone epiphyses and diaphyses (notably two femurs and one tibia) (Fig. 12a) and four indeterminate bones. They are related to disarticulation and defleshing on fresh carcasses. The marks on zygomatic bones are situated on the insertion zone of the auricular muscle. It does not seem to be related to mandibula disarticulation, but rather result from taking off the ears.

Three mammoth bone fragments and two adult femurs show fresh fractures on the distal and proximal condyles (Fig. 12b), resulting from the extraction and consumption of the marrow by humans. The high level of representation of diaphyses compared to epiphyses could be explained by the fracturing and consumption of nutrients present in the spongiosa.

Mammoth bones with anthropogenic marks are located in the pit. Short bones of other mammals, found in association with hearths inside the circular structure, were described as whitened, probably because of boiling (Chernysh, 1982). 
Table 1

The faunal spectrum from Molodova I layer 4.

\begin{tabular}{|c|c|c|c|c|c|}
\hline Order & Family & Species & NISP & MNE & cMNI \\
\hline \multirow[t]{3}{*}{ Carnivores } & Canidae & Canis lupus & 1 & 1 & 1 \\
\hline & & Vulpes vulpes & 2 & 2 & 1 \\
\hline & Felidae & Panthera pardus & 8 & 7 & 1 \\
\hline Subtotal & & & 11 & 10 & 3 \\
\hline \multirow[t]{2}{*}{ Proboscideans } & Elephantidae & Mammuthus primigenius & 1695 & 482 & 15 \\
\hline & & Ind. & 328 & - & - \\
\hline Subtotal & & & 2023 & 482 & 15 \\
\hline \multirow[t]{6}{*}{ Artiodactyls } & Cervidae & Cervus elaphus & 59 & 32 & 4 \\
\hline & & Rangifer tarandus & 60 & 7 & 3 \\
\hline & & Ind. & 11 & 11 & - \\
\hline & Bovidae & Bison priscus & 39 & 30 & 3 \\
\hline & & Ind. & 16 & 5 & - \\
\hline & Ind. & & 14 & 10 & - \\
\hline Subtotal & & & 199 & 95 & 10 \\
\hline \multirow[t]{2}{*}{ Perissodactyls } & Equidae & Equus cf. latipes & 20 & 19 & 3 \\
\hline & Rhinocerotidae & Coelodonta antiquitatis & 30 & 22 & 1 \\
\hline Subtotal & & & 50 & 41 & 4 \\
\hline Total & & & 2283 & 628 & 32 \\
\hline Very large herbivores & & & 8 & & \\
\hline Large herbivores & & & 83 & & \\
\hline Herbivores & & & 11 & & \\
\hline Not identified mammals & & & 53 & & \\
\hline Total number of not identified remains & & & 155 & & \\
\hline Total number of remains & & & 2438 & & \\
\hline
\end{tabular}

NISP = number of identified specimens; MNE = minimum number of elements; cMNI = combined minimum number of individuals (defined by Poplin, 1983).

\subsubsection{Non-food related modifications}

Two reinder antlers bear cutmarks on the medial side and at the basis of a tine. One is located in the pit and the other one in the bone circular accumulation (Fig. 12c). These extracted antlers do not seem to have been used afterwards. A third antler seems to have been used as a percutor (according to the definition in PatouMathis et al., 2005). One cervid rib, one horse tibia, and an indeterminate fragment of long bone of a large mammal situated near the pit in the so-called "symbolic" area, were covered with ochre (Chernysh, 1982).

One mammoth tusk bears cutmarks that can be interpreted as indicative of extraction (Fig. 12d). There is no other worked ivory at the site.
Three mammoth bones exhibit specific series of parallel striations (Chernysh, 1982; Nowell and d'Errico, 2007), which do not seem characteristic of butchery activities. One series of nine striations was observed on the medial side of a scapula, one series of seven parallel striations on a glenoidal cavity (Fig. 12e), and one series of thirteen striations on an innominate (Fig. 12f). The striations are more or less deep and result from intentional interaction with a lithic tool, but are not related to butchering processes. These bones were located at the east and west areas near the circular structure and the pit.

Artistic engravings were previously described (Goretsky and Ivanova, 1982), notably two human figures: one on a cranial fragment of a horse or a bison; the other one on a bison rib. Recent

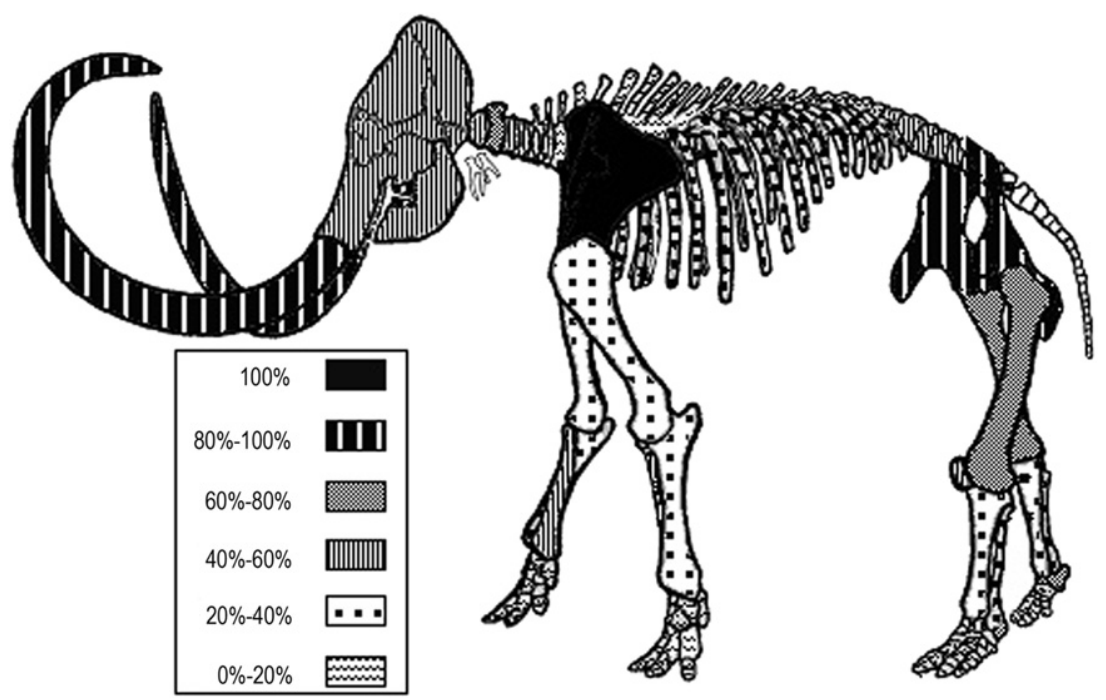

Fig. 9. Skeletal preservation of the mammoth from Molodova I layer 4 (Ps\%). 
Table 2

Anatomical representation of mammoth bones from Molodova I layer 4 .

\begin{tabular}{|c|c|c|c|c|c|c|c|c|c|c|}
\hline \multirow[t]{2}{*}{ Elements } & \multirow[t]{2}{*}{ NISP } & \multicolumn{3}{|c|}{ MNE } & \multicolumn{5}{|c|}{ cMNI } & \multirow[t]{2}{*}{ Ps\% } \\
\hline & & $\mathrm{L}$ & $\mathrm{R}$ & Ind. & Juv. & Sub. & Ad. & $\mathrm{Ad}+$. & Tot. & \\
\hline Skull & 61 & & & & 1 & 2 & 1 & & 7 & 46.67 \\
\hline Petrousal bone & 3 & & & & & & & & 2 & 10.00 \\
\hline Mandible & 55 & 6 & 10 & & 2 & 2 & 1 & & 11 & 53.33 \\
\hline Teeth (total) & 56 & 11 & 16 & 17 & 2 & 7 & 5 & & 14 & 36.67 \\
\hline Upper teeth & 19 & 4 & 9 & 4 & 2 & & 3 & & 5 & 28.33 \\
\hline Lower teeth & 23 & 7 & 7 & 7 & 1 & & 6 & & 7 & 35.00 \\
\hline Ind. teeth & 14 & & & & 1 & & 1 & & 2 & 5.00 \\
\hline Tusk & 111 & 2 & & 4 & 2 & 1 & & & 10 & 63.33 \\
\hline Atlas & 14 & & & & & & 2 & & 8 & 53.33 \\
\hline Epistropheus & 12 & & & & & 1 & & & 11 & 73.33 \\
\hline Cervical vertebra & 50 & & & & 1 & 1 & 1 & & 7 & 44.00 \\
\hline Thoracic vert. & 102 & & & & 1 & 1 & 1 & & 3 & 14.67 \\
\hline Lumbar vert. & 55 & & & & 1 & & 2 & & 7 & 48.00 \\
\hline Sacrum & 4 & & & & & & & & 3 & 20.00 \\
\hline Caud. vert. & & & & & & & & & & 0.00 \\
\hline Ribs & 624 & 16 & 12 & 37 & 1 & 1 & 2 & 1 & 5 & 22.67 \\
\hline Sternum & 2 & & & & & & 2 & & 2 & 13.33 \\
\hline Scapula & 88 & 11 & 15 & 3 & 2 & 2 & 2 & & 15 & 96.67 \\
\hline Humerus & 26 & 6 & 4 & & 1 & 2 & 1 & & 6 & 33.33 \\
\hline Radius & 27 & 9 & 4 & & 1 & 3 & 1 & 1 & 6 & 43.33 \\
\hline Ulna & 39 & 4 & 4 & 3 & 1 & 1 & 2 & & 6 & 36.67 \\
\hline Carpals & 25 & 13 & 7 & 41 & 1 & & 2 & & 15 & 11.87 \\
\hline Metacarpals & 7 & 5 & 2 & & & & & & 1 & 7.75 \\
\hline Innominate & 61 & & & & 2 & 3 & 1 & & 13 & 86.67 \\
\hline Femur & 111 & 10 & 7 & 2 & 1 & 2 & 1 & & 10 & 63.33 \\
\hline Patella & 15 & 3 & 5 & 5 & 1 & 1 & 1 & & 7 & 43.33 \\
\hline Tibia & 27 & 6 & 5 & & 1 & 1 & 1 & 1 & 6 & 36.67 \\
\hline Fibula & 23 & 3 & 3 & 1 & 1 & 1 & 1 & 1 & 6 & 23.33 \\
\hline Talus & 46 & 17 & 9 & 11 & 1 & 1 & 3 & & 11 & 18.2 \\
\hline Metatarsials & 5 & & 4 & & & & & & 1 & 4.67 \\
\hline Carpals/tars. Ind. & 20 & & & & & & & & 1 & 3.53 \\
\hline Metapodials ind. & 14 & & 2 & & 1 & & 1 & & 2 & 2.33 \\
\hline Phalanxes & 10 & & & & 1 & & 1 & & 2 & 2.2 \\
\hline Sesamoids & 1 & & & & & & & & 1 & 3.33 \\
\hline
\end{tabular}

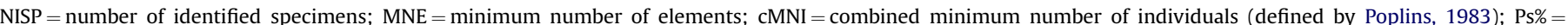
percentage of survival.

works demonstrated that they are in fact blood vessels marks and a modern figure (Nowell and d'Errico, 2007).

Mammoth bones covered with ochre were found in the socalled "symbolic" area (Chernysh, 1982): four flat bones, three axial skeleton bones and three bone fragments of at least one adult and a juvenile. Bones from other mammals (cervid and horse) covered with ochre were discovered in this area.

\section{Discussion}

\subsection{Mammoth acquisition}

In Molodova I layer 4, all age classes are represented in the mammoth mortality curve, which shows a predominance of young and mature adults over juveniles, intermediate and old adults.
The expected age profile of slaughtered mammoths is characterized by a majority of juveniles and young adults, as shown in Taubach (Bratlund, 1999), Salzgitter-Lebenstedt (Gaudzinski, 1999) and Milovice G (Péan, 2001). The only site which is characterized by the slaughtering of old individuals is Vogelherd (Niven, 2001). Conversely, naturally deceased mammoths are expected to be mostly juveniles and old individuals (Haynes, 1991). The mammoth age profile from Molodova I layer 4 would refer to multiple terms of acquisition by humans.

At least one adult individual has been slaughtered, as shown by a hunting impact. The hunted mammoths were probably naturally trapped as the uneven region was favorable to this kind of practice.

A juvenile died at about three months. This could indicate that it either was slaughtered or naturally died during the early summer season.
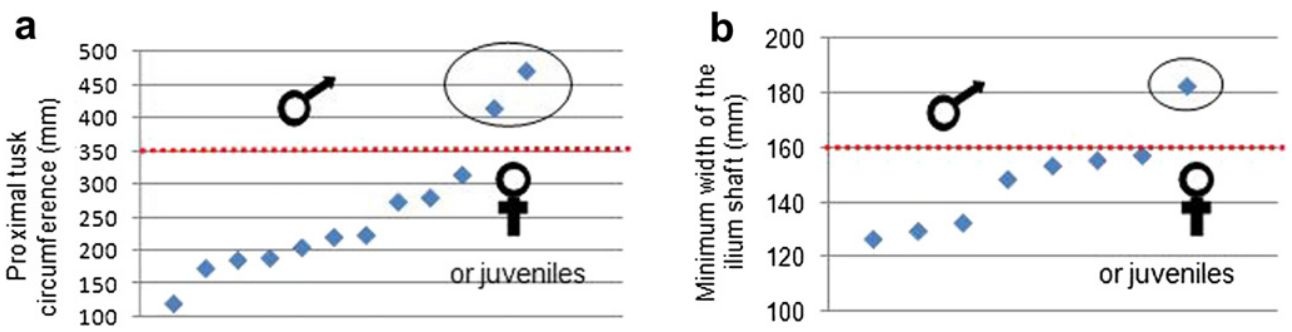

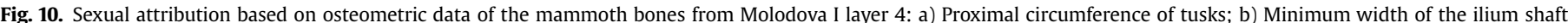

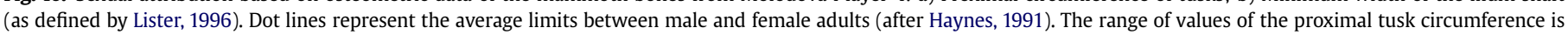
200-350 $\mathrm{mm}$ by adult females. 


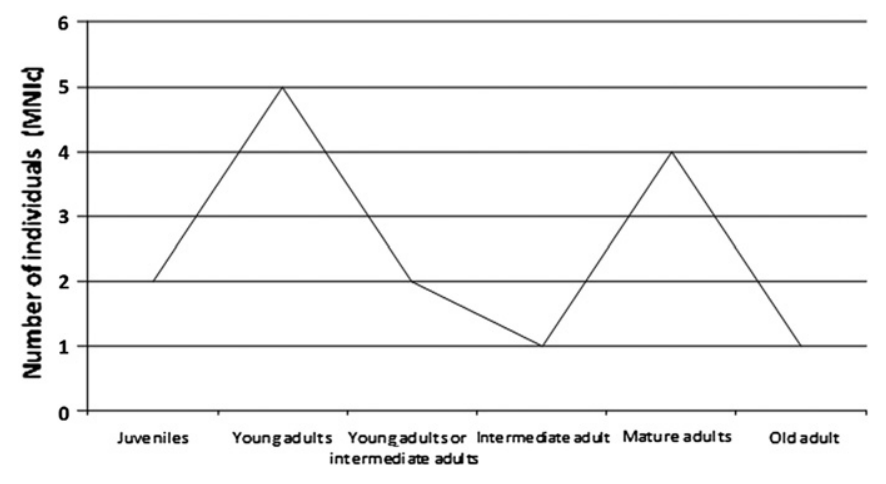

Fig. 11. Mortality profile of the mammoths from Molodova I layer 4.

Several series of vertebrae were discovered in anatomical position: two series of two cervical vertebrae, five series of two thoracic vertebrae, four series of two lumbar vertebras, and one series of three lumbar vertebrae. Cutmarks on zygomatic bones, vertebrae, ribs, innominates and long bones (tibia, femur) show that they were disarticulated and the meat was removed. These observations show that Neanderthals accessed fresh mammoth carcasses by hunting or scavenging. Other indications of mammoth scavenging will be discussed below (cf. 5.2.1). Some long and flat bones, which show numerous plant root marks, were probably collected from dried carcasses.

The mammoths from Molodova I layer 4 would have resulted from different modes of acquisition, mostly hunting plus scavenging and collecting, through several episodes of human activities. Neanderthals are known to have diversified behaviors, oriented to hunting associated with collection of carcasses of large mammals, as evident in Payre (France), Scladina (Belgium), Kůlna (Czech Republic) and Krapina (Croatia) (Patou-Mathis, 2002).

In Molodova I layer 4, Neanderthals acquired different herbivore species (mammoth, bison, reindeer and red deer) but oriented the game procurement towards mammoth, by hunting and scavenging. Other Middle Paleolithic sites with a important representation of mammoth are known, such as Molodova 5, Ripiceni Izvor (Paunescu, 1992), Raj Cave (layer 6, Poland) (Wojtal and PatouMathis, 2003) but in Molodova I layer 4 the predominance of mammoth is exceptional.

\subsection{Mammoth processing}

\subsubsection{Food}

Different butchering processes by Neanderthals were evident on the mammoths from Molodova I layer 4. Disarticulation marks have been described on shoulders, hips and necks. Peculiar scraping marks on the body of long bones (femurs, tibias) indicate the removal of meat from rear limb parts. One particularity of this assemblage is the deep striations on mammoth bones. This is unusual with this kind of butchering processing (Scott, 1980; Crader, 1983). These unusual deep and serial marks on mammoth bones could result from a particularly emphasized gesture of defleshing and disarticulation of carcasses, probably from scavenged animals.

Long bone marrow was removed for consumption. This evidence of meat and marrow consumption is shown in all age classes and both males and females. These data demonstrate that Neanderthal consumed mammoth meat in Molodova I. The bone material which exhibits these food activities was recovered from the pit. Therefore, the filling of the pit resembles refuse material from mammoth processing for food resources.

Considering that about $500 \mathrm{~kg}$ of flesh could be yielded by one adult mammoth (Haynes, 1991), the available quantity of meat from at least fifteen mammoths in Molodova I layer 4 suggests longtermed or recurrent occupations by a large number of people.

According to Chernysh (1982), carpals, tarsals and phalanges of other mammals species (red deer, reindeer and bison) were used for bone grease production. Those remains were found near the hearths in the circular bone accumulation.

\subsubsection{Non-food}

In the bone assemblage from Molodova I layer 4, the series of striations observed on mammoth dried scapulas and innominate could be interpreted as symbolic representations. Goretsky and Ivanova (1982) interpreted them as calendars.

Cranial, axial and girdle skeletal elements have been recovered with ochre. Neanderthals are known to have used ochre which could be related with skin hydration or body aestheticism. It would be related to symbolism (Soressi and d'Errico, 2007). Mammoth bones covered with ochre have been described in other Middle Paleolithic sites: Arcy-sur-Cure (grotte du Renne, Mousterian, France) (Chase and Dibble, 1987) and Tata (Taubachien, Hungary) (Moncel, 2003; Patou-Mathis, 2004).

\subsection{Mammoth bones used as building material}

The ring-shaped basement of the circular bone structure measures 5 by $8 \mathrm{~m}$ inside and 7 by $10 \mathrm{~m}$ outside. According to Chernysh (1982), the structure is composed of 116 complete large bones of mammoth: twelve skulls, five mandibles, fourteen tusks, thirty-four girdle bones and fifty-one long bones (Table 4; Fig. 13). The following bones from this circular accumulation were analyzed: two mandibles, two tusks (one juvenile, one adult), nine vertebrae, isolated and in anatomic position (one juvenile and at least an adult), five girdle bones (notably one juvenile innominate), and fifteen long bones (two femurs, two fibulas, three tibias, one ulna of juvenile and seven long bone diaphyses). The adult bones included both males and females. Except for the juvenile elements, the bones mostly result from a selection of large and strong skeletal elements, which have been arranged and imbricated. The choice of bone elements is a pertinent clue to recognize a built structure (Péan and Patou-Mathis, 2003). Most of the bones composing the circular accumulation have been selected and intentionally assembled by Neanderthals to build a ring-shaped structure (Table 3).

Table 3

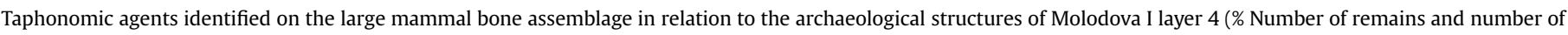
remains).

\begin{tabular}{|c|c|c|c|c|c|c|c|c|c|c|}
\hline \multirow[t]{2}{*}{ Agent structure } & \multicolumn{2}{|c|}{$\begin{array}{l}\text { Water } \\
\text { (percolation) }\end{array}$} & \multicolumn{2}{|c|}{ Weathering } & \multicolumn{2}{|c|}{ Plants } & \multicolumn{2}{|c|}{ Carnivores } & \multicolumn{2}{|c|}{ Humans } \\
\hline & $\%$ NR & NR & $\%$ NR & NR & $\% \mathrm{NR}$ & NR & $\%$ NR & NR & $\%$ NR & NR \\
\hline Circular bone structure & 3.5 & 85 & 3 & 73 & 2 & 48 & 0 & 0 & 0.1 & 2 \\
\hline Pit & 13.3 & 324 & 6 & 146 & 2 & 48 & 3 & 73 & 1.1 & 26 \\
\hline
\end{tabular}



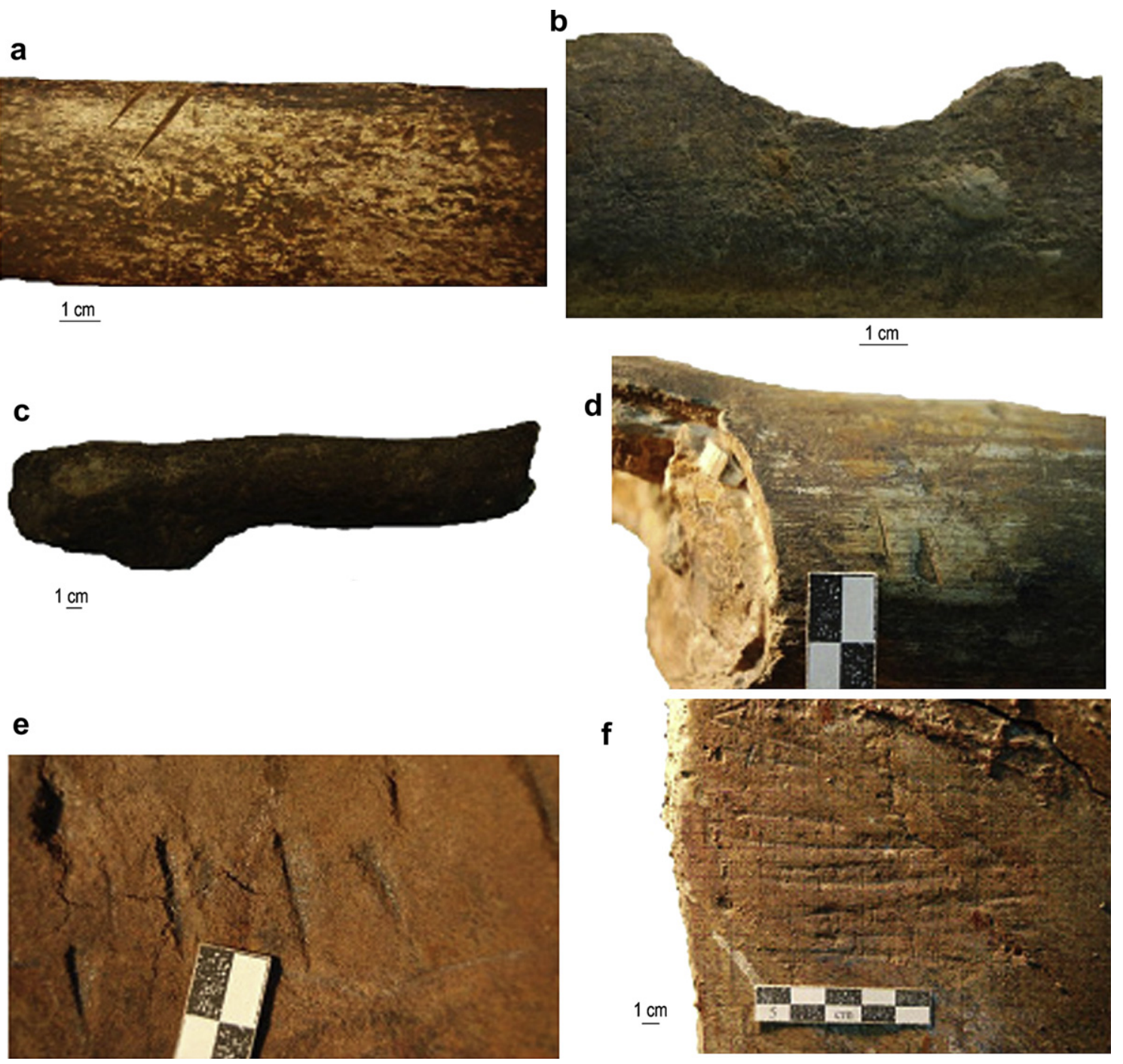

Fig. 12. Human modifications on bones from Molodova I layer 4: a) Butchering cutmarks on a mammoth rib; b) Fracture impact on long bone diaphysis of mammoth; c) Reindeer antler probably used as percutor; d) Sharp grooves on a mammoth tusk; e) Series of parallel sharp grooves on the glenoidal cavity of a mammoth scapula; f) Series of parallel sharp grooves on a mammoth innominate (Photo: S. Péan).

The taphonomic data showed that the bones of the circular structure were mostly modified by water infiltration; they must have stayed for a long period of time in holes, perhaps dug by humans. The weathering is characteristic of an extended exposure to open air, so these bones were probably the last to be buried. The bones of the ring-shaped assemblage present no carnivore or human marks. Neanderthals could have kept bones of fresh carcasses and collected bones of dried carcasses to build this circular structure.

The Upper Paleolithic structures made of mammoth bones are composed of 150-650 bones coming from 10-95 mammoth

Table 4

Anatomical distribution of mammoth elements between the pit and the circular bone accumulation from Molodova I layer 4 (MNE).

\begin{tabular}{|c|c|c|c|c|c|c|c|}
\hline \multirow[t]{3}{*}{ Structure element } & \multicolumn{4}{|c|}{ Circular bone accumulation } & \multirow{2}{*}{\multicolumn{3}{|c|}{ Pit }} \\
\hline & \multirow{2}{*}{$\frac{\text { After Chernysh (1982) }}{\text { All age classes }}$} & \multicolumn{3}{|l|}{ New data } & & & \\
\hline & & Juveniles & Adults & Indeterminate & Juveniles & Adults & Indeterminate \\
\hline Skulls & 12 & & & & & 1 & 1 \\
\hline Mandibles & 5 & & & 2 & 1 & & 6 \\
\hline Tusks & 14 & 1 & & 1 & & & 3 \\
\hline Teeth & 15 & & 4 & 1 & 2 & & \\
\hline Axial skeleton & & 1 & & 8 & 2 & & \\
\hline Ribs & & & & 4 & & & 40 \\
\hline $\begin{array}{l}\text { Girdle bones } \\
\text { (scapulas and innominates) }\end{array}$ & 34 & 1 & & 4 & & & 11 \\
\hline Long bones & 51 & 1 & 4 & 10 & & 3 & 13 \\
\hline Autopodial bones & & & & 5 & & & 10 \\
\hline
\end{tabular}




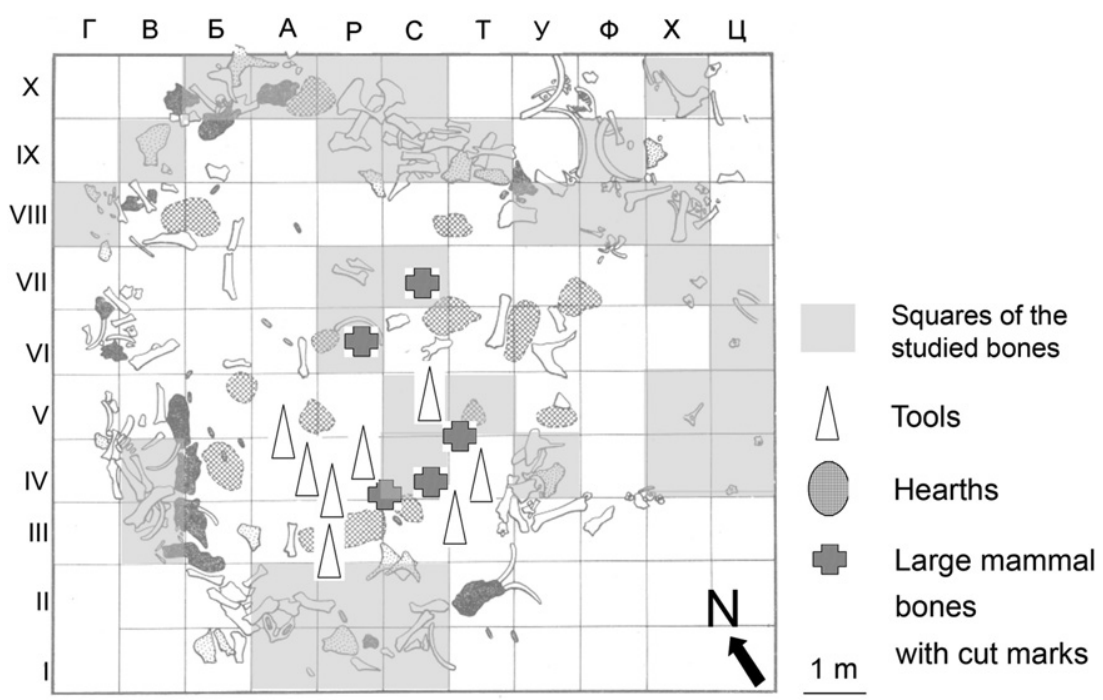

Fig. 13. Plan of the circular structure made of mammoth bones in Molodova I layer 4 (modified after Ivanova, 1964).

carcasses (Oliva, 1988). The structures can measure from 5 to $9 \mathrm{~m}$ in diameter. In Ukrainian Epigravettian sites, the ring-shaped foundation of the bone structure from Mezhirich is composed of skulls and mandibles, whereas the bone structure from Dobranichevka is composed of skulls, long bones, mandibles and scapula (Pidoplichko, 1998). In Molodova I layer 4, the choice of bones is quite similar. However, comparing the diameter of the structure, the number of bones is lower. Moreover, the ulna and tusk of juvenile, fibula and vertebrae of adults do not seem adequate for building. They are too fragile to support a heavy structure such as a bone roof. Thus, this circular accumulation of mammoth bones can be interpreted as a base of a wooden structure or as a wind screen.

The use of bones as building elements can be appreciated as anticipation of climatic variations (Svoboda et al., 2005). Under a cold climate in an open environment, the lack of wood led humans to use bones to build protections against the wind. In Molodova I layer 4, Neanderthals adapted to the environmentally hard conditions.

\subsection{Function of the bone structure and the pit}

Red deer and bison bones with butchering marks are located inside the bone structure near the hearths. Chernysh (1982) described short bones of large mammals used for storage. Two reindeer antlers were present. One shows cut marks. Mammoth teeth and metapodials are also near the hearths. These bones were associated with abandoned tools used to butcher (Fig. 7). Use wear studies on flint tools show traces of wood work (Chernysh, 1982). According to taphonomic features indicating trampling, humans probably actively walked at this place. An ochre deposit is located inside (Fig. 7), probably used to re-cover the bones described above. The inner space of the structure is characterized by a spatial distribution of hearths, cooking areas and flint workshop, which are mostly located in the southern half. The bone structure was used as a domestic area, probably the central place of the layer 4 settlement. The high number of hearths and the location of three of them among the ring-shaped accumulation of bones support the hypothesis of repeated settlement.

The pit, which is located $9 \mathrm{~m}$ from the circular structure, was identified by the quantity of accumulated bones and taphonomic features. It contains the majority of animal bones, in particular ribs which are all fragmented and bear cut marks. The concentration of carnivore gnawing marks on this bone material would have occurred after the human butchery activity. This supports the interpretation of a deposit of butchery waste of mammoth.

Several mammoth bones (long bones, scapulas, tusks) from the pit and the dwelling structure can be linked to the same individuals. The anatomical correspondence of these bones suggests that these two areas were related with a contemporary utilization.

Most Mousterian dwellings are known to have been established in caves for protection against cold and humidity. Several open-air camps exhibit stone paving and roof wood structures (Champ-Grand, France) (Popier, 1982) or isolated dwelling structures (Fontmaure) (Bosinski, 2004). Other Neanderthal dwelling structures in mammoth bones have been described, in Molodova 5 layer 11 and Ripiceni-Izvor (Romania) (Paunescu, 1992). The last groups of Neanderthals would have built mammoth bone structures, according to the Szeletian sites Dzierzyslaw and Vedrovice 5 (Valoch, 1984), and the Soungirian settlement in Kostienki 1 (Rogatchev, 1957). However, they are not verified. New taphonomical studies should permit new answers. At present, the Molodova I layer 4 is the only attested Middle Paleolithic mammoth bone structure.

\subsection{Site function}

The data allow definition of the main activities of the human settlement in Molodova I layer 4 (Figs. 4 and 13). The butchery activities on such a quantity of mammoths, the fifteen individuals associated with other consumed mammals, indicates a large number of people. Moreover, the hunting marks on one mammoth suggest the possibility of a kill and butchery place. Other sites show a largescale and complex hunting organization where humans could store meat, such as Kabazi II (Patou-Mathis and Chabaï, 2003) and Bau de l'Aubesier (Fernandez and Legendre, 2003). In Molodova I layer 4, part of the meat must have been consumed directly at the site, because of the important evidence of butchering and flint artifact work. The high number of hearths and the marks of combustion on small bones, observed on one fragment of a long bone diaphyse, were interpreted by Chernysh (1982) as indicating meat cooking and smoking. Part of the meat could have been taken elsewhere. The extraction of deer antlers and mammoth tusks suggests the intention of future use in or out of the site. 
The number (40 000) and varied types of lithic artifacts suggest a long or recurrent occupation. These lithic artifacts were made on raw material from the terrace deposits. Layer 4 could also be a place of lithic workshop. The presence of a flint deposit would have been an important reason to set up a camp in the area. In contrast with the Upper Paleolithic, the Middle Paleolithic human groups did not show mobility to obtain raw material, apart from the volcanic Eifel site (Bosinski, 2004). In Molodova I layer 4, Neanderthals abandoned a part of their tools. Some artifacts could be used only for an important occasional hunt (Auguste et al., 1998) but the Molodova I layer 4 is not a short-term camp. The construction of a bone structure must have taken a long time. Such a work implies a consequential human establishment.

The quantity of mammoths (at least fifteen individuals), the number of artifacts and the construction of such a structure are characteristic of a temporary and recurrent camp. This could be a gathering place for a numerous human groups (Desbrosse and Kozlowski, 1994).

The choice of the occupation site could be explained by the river proximity, as water is an essential resource. Moreover, the presence of forests should have provided some protection against the cold climate. The height of the location should permit avoiding unexpected animal or human confrontations. It also could have been useful to observe and trap prey, or even to locate carcasses. Neanderthals could live in different environments such as plateaux, plains, and caves, but generally open air sites were used for slaughtering and butchering activities (Otte et al., 2001). Moreover, human groups gave generally priority to these small geological depressions to set up seasonal camps. The Molodova I layer 4 is a strategic place for recurrent occupations.

\section{Conclusions}

The bone assemblage of Molodova I layer 4 is dominated by mammoth, with a population estimated of at least fifteen individuals of all age classes, and both males and females. Taphonomical data indicated that the faunal remains did not undergo major postdepositional modifications, with emphasized actions of weathering, water infiltration and plant root marks in the pit and the circular bone accumulation. Indices of bone repartition and conservation allowed characterization of the different conditions of areas and the use of the structures, including a pit with fragmented bones, mainly ribs, on the other hand, a circular bone accumulation composed of complete skulls, tusks, vertebrae, girdle bones and long bones. Mammoth acquisition was based on hunting, as directly attested to by at least one individual, and scavenging as shown by the scraper marks. The collection of dried bones from carcasses was also part of the procurement strategy. Bone processing was intensive with numerous human marks, usually poorly represented on mammoth remains. Several long bones were fractured for the extraction of marrow. Other mammal bones (reindeer, red deer and bison) were also butchered and formed domestic refuse in the circular accumulation. Low data on other species ruled out identification of seasonality. The different species were skinned, disarticulated and defleshed in the excavated area. These remains demonstrate repeated human activities. Mammoth bones were also used for non-food modalities. Indeed some of their parts were re-covered with ochre, and others have parallel striations that are not related to butchery. Eventually, Neanderthals selected mammoth bones and built a ring-shaped structure. Inside the structure, the presence of hearths, cooking activity area and flint workshops correspond to a domestic area. The number of mammoths, the available quantity of meat, the number and varied types of lithic artifacts, and the space settlement indicate that Layer 4 of Molodova I was a recurrent camp for numerous people.
Layer 4 from Molodova I is an important reference to understand the modalities of large mammal acquisition by Neanderthals and in particular the use of mammoth. The built structure of mammoth bones associated with a pit appears to be the oldest one set up by Neanderthals. There may not have been a gap between Middle and Upper Paleolithic in the use of mammoth bones as building material for dwelling structures. It is of interest to enlarge comparisons with $H$. sapiens subsistence modalities with the purpose to appreciate a possible knowledge transmission from Neanderthals.

\section{Acknowledgments}

We would like to thank OleksandrSytnik (Museum of Archeology, Lviv) and Larissa Koulakovska (Museum of Archaeology, Kyiv) for the access to the collections, Jura Pryskurnjak for his participation, and the organizers of the Vth International Mammoth Conference in Le Puy en Velay. The research was supported by a French-Ukrainian project (coordinated by M. Patou-Mathis and L. Koulakovska), as part of the cooperation program between the CNRS and the National Academy of Sciences of Ukraine.

\section{References}

Agadzhanian, A.K., 1982. Small mammals from the section of the Molodova I site. In: Goretsky, G.I., Ivanova, I.K. (Eds.), Molodova I: Unique Settlement on the Middle Dniestr Region. Nauka, Moscow, pp. 154-173 (in Russian).

Auguste, P., Moncel, M.H., Patou-Mathis, M., 1998. Chasse ou «charognage»: acquisition et traitement des rhinocéros au Paléolithique moyen en Europe occidentale. In: Brugal, J.P., Meignen, L., Patou-Mathis, M. (Eds.), Economie préhistorique: les comportements de subsistance au Paléolithique. Actes de la XVIIIe Rencontres internationales d'Archéologie et d'Histoire d'Antibes, APDCA, Sophia-Antipolis, pp. 133-151.

Behrensmeyer, A.K., 1978. Taphonomic and ecologic information from bone weathering. Paleobiology 4 (2), 150-162.

Binford, L.R., 1983. In Pursuit of the Past. Decoding the Archaeological Record. Thames and Hudson, London.

Botez, I.G., 1930. Date paleolitice pentru stratigrafia loessului în nordul bessarabiei. Academia Romaňa, Memoriilesectiuniistiințifice, III 7 (5), 108-118.

Botez, I.G., 1933. Recherches sur la Paléontologie Humaine au Nord de la Bessarabie. Annales Scientifiques de l'Université de Iaşi 17 (3-4), 397-471 (in Romanian).

Bouchud, J., 1952. Etude des Rongeurs et des Oiseaux de l'abri Castanet. Bulletin de la Société préhistorique française 49 (5-6), 267-271.

Bosinski, G., 2004. Le Paléolithique moyen. In: Krause, E.B. (Ed.), Les hommes de Néandertal, Le feu sous la glace, 250000 ans d'histoire européenne. Editions Errance, Paris, pp. 55-64.

Bratlund, B., 1999. Anthropogenic factors in the thanatocoenose of the last interglacial travertines at Taubach. In: Gaudzinski, S., Turner, E. (Eds.), The Role of Early Humans in the Accumulation of European Lower and Middle Palaeolithic Bone Assemblages. Monographien des Römisch-germanischen Zentralmuseums, vol. 42. Habelt, Mainz \& Bonn, pp. 255-262.

Chase, P.G., Dibble, H.L., 1987. Middle paleolithic symbolism: a review of current evidence and interpretations. Journal of Anthropological Archaeology 6 (3), 263-296.

Chernysh, A.P., 1960. Ostatki must'erskogo zhilischa na Dnestre. Sovetskaja etnografija $1,149-152$ (in russian).

Chernysh, A.P., 1965. Ranniï i sredniï paleolit Pridnestrov'ja. Nauka, Moskva (in Russian).

Chernysh, A.P., 1982. Paleolithic multilayered Molodova I site. In: Goretsky, G.I., Ivanova, I.K. (Eds.), Molodova I: Unique Mousterian Settlement on the Middle Dniestr Region. Nauka, Moscow, pp. 6-102 (in russian).

Chernysh, A.P., 1983. A Mousterian dwelling in the Dnestr area. Arkheolohiia 44, 3-6.

Chernysh, A.P., 1989. O mustyerskikh zhilishchakh i poseleniyakh. In: Bibikov (Ed.), Kamennyvek Pamyatniki, metodika, problemy. Naukova dumka, Kiev, pp. $72-81$ (in Russian).

Crader, D.C., 1983. Recent single-carcass bone scatters and the problem of «butchery sites in the archaeological record. In: Clutton-Brock, J., Grigson, C. (Eds.), Animals and Archaeology. Hunters and Their Prey. British Archaeological Reports, International Series $\mathrm{N}^{\circ} 163$, Oxford, vol. 1, pp. 107-141.

Desbrosse, R., Kozlowski, J., 1994. Les habitats préhistoriques: Des Australopithèques aux premiers agriculteurs. Editions du CTHS/Université Jagellon, Paris/Cracovie.

Eisenmann, V., 2010. L'évolution des Equidés. Le cheval: monture, nourriture et figure, Etudes mongoles et sibériennes, centrasiatiques et tibétaines 41.

Faure, M., Guérin, C., 1984. Sus strozzi et Sus scrofa, deux mammifères artiodactyles marqueurs des paléoenvironnements. Palaeogeography, Palaeoclimate, Palaeoecology $48,215-228$. 
Fernandez, P., Legendre, S., 2003. Mortality curves for horses from the Middle Palaeolithic site of Bau de l'Aubesier (Vaucluse, France): methodological, palaeo-ethnological, and palaeo-ecological approaches. Journal of Archaeological Science 30 (12), 1577-1598.

Gaudzinski, S., 1999. Middle Palaeolithic bone tools from the open-air site Salzgitter-Lebenstedt (Germany). Journal of Archaeological Science 26 (2), 125-141.

Goretsky, G.I., Ivanova, I.K., 1982. Molodova I: Unique Mousterian settlement on the middle Dniestr Region. Nauka, Moscow.

Haynes, G., 1991. Mammoths, Mastodonts and Elephants, Biology, Behavior and the Fossil Record. Cambridge University Press, Cambridge.

Hoffecker, J.F., 2002. Desolate Landscapes: Ice-Age Settlement in Eastern Europe. Rutgers University Press, New Brunswick.

Ivanova, I.K., 1958. O geologicheskikh uslovijakh nakhozhdenija verkhnepaleoliticheskoï stojanki Molodova I (Baïlova Ripa). BKIChP 22 Moskva (in Russian).

Ivanova, I.K., 1964. Role of Geological Structure and Palaeogeographical Conditions in the Dispersal of Ancient Man (as Exemplified by the Basin of the River Dniestr), vol. 4. INQUA, Warsaw, pp. 311-323.

Ivanova, I.K., 1982. Geology and paleogeography of Molodova I Mousterian settlement In: Goretsky, G.I., Ivanova, I.K. (Eds.), Molodova I: Unique Mousterian Settlement on the Middle Dniestr Region. Nauka, Moscow, pp. 188-235 (in Russian).

Kernd'l, A., 1963. GebautedauerhafteBehausungenbereitsimMousterien: zusowjetischenGrabungsergebnissen (La construction d'habitats permanents dès le Moustérien: d'après les résultats de fouilles soviétiques). Berliner Blätter für Vor- und Frühgeschichte 10 (1), 41-45.

Klein, R.G., 1989. The Human Career. Human Biological and Cultural Origins, first ed. The University of Chicago Press, Chicago and London.

Klein, R.G., 1999. The Human Career. Human Biological and Cultural Origins, second ed. The University of Chicago Press, Chicago and London.

Kolen, J., 1999. Hominids without homes: on the nature of Middle Paleolithic settlement in Europe. In: Roebroeks, W., Gamble, C. (Eds.), The Middle Paleolithic Occupation of Europe. University of Leiden Press, Leiden, pp. 139-175.

Lister, A.M., 1996. Sexual dimorphism in the mammoth pelvis: an aid to gender determination. In: Shoshani, J., Tassy, P. (Eds.), The Proboscidea: Evolution and Palaeoecology of Elephants and Their Relatives. Oxford University Press, New York, pp. 254-259.

Moncel, M.H., 2003. Tata (Hongrie). Un assemblage microlithique du début du Pléistocène supérieur en Europe centrale. L'Anthropologie 107 (1), 117-151.

Moroşan, N.N., 1929. Noi contribuţii preistorice asupra Basarabiei de Nord. Academia Română, Memoriile secţiunii științifice, seria 3,6 (1), 34-45.

Moroșan, N.N., 1931. Le Moustérien dans le Nord de la Moldavie. L'Anthropologie 41, 234-235.

Moroşan, N.N., 1938. Le Pléistocène et le Paléolithique de la Roumanie du Nord-Est (les dépôts géologiques, leur faune, flore et produits d'industrie). Anuarul Institutului Geologic al României 19, 3-160.

Niven, L., 2001. The role of mammoths in Upper Palaeolithic economies of southern Germany. In: Cavarretta, G., Gioia, P., Mussi, M., Palombo, M. (Eds.), La Terra degli Elefanti - The World of Elephants, Proceedings of the 1st International Congress. CNR, Rome, pp. 323-327.

Nowell, A., d'Errico, F., 2007. The Art of Taphonomy and the Taphonomy of Art: Layer IV, Molodova I, Ukraine. Journal of Archaeological Method and Theory 14 (1), 1-26.

Oliva, M., 1988. A Gravettian site with mammoth-bone dwelling in Milovice (Southern Moravia). Anthropologie (Brno) 26, 105-112.

Otte, M., Bonjean, D., Patou-Mathis, M., 2001. Contractions Temporelles au Paléolithique de Sclayn: L'Utilisation de différents Paysages. In: Conard, N. (Ed.), Settlement Dynamics of the Middle Paleolithic and Middle Stone Age. Kerns Verlag, Tübingen, pp. 267-291.

Patou-Mathis, M. (Ed.), 1994. Taphonomie - Bone Modification. Editions du Centre d'Etudes et de Documentations Archéologiques, Treignes.

Patou-Mathis, M., 2002. Comportements de subsistance durant le Dernier Interglaciaire en Europe. In: Tuffreau, A., Roebroeks, W. (Eds.), Le Dernier Interglaciaire et les occupations humaines du Paléolithique moyen. CERP, $n^{\circ} 8$, Villeneuve d'Asq, pp. 53-65.
Patou-Mathis, M., Chabaï, V., 2003. Kabazi II (Crimée, Ukraine): un site d'abattage et de boucherie du Paléolithique moyen. L'Anthropologie 107 (2), 223-253.

Patou-Mathis, M., 2004. Nouvelle analyse de la faune de Tata (Hongrie). In: Kissné Cseh, J. (Ed.), Topical Issues of Research of Middle Palaeolithic Period in Centra Europe, Actes du Congrès de Tata (Hongrie), 20-23 Octobre 2003. Tudomanyos Füzetek 12, 179-190.

Patou-Mathis, M., Péan, S., Vercoutère, C., Auguste, P., Laznickova-Gonysevova, M. 2005. Réflexions à propos de l'acquisition et de la gestion de matières premières animales au Paléolithique. Exemples: mammouth/ivoire-renne/bois. In: Vialou, D., Renault-Miskovsky, J., Patou-Mathis, M. (Eds.), Comportements des hommes du Paléolithique moyen et supérieur en Europe: territoires et milieux. Etudes et recherches archéologiques de l'Université de Liège, Liège, pp. 27-38.

Paunescu, A., 1992. Ripiceni-Izvor. Le Paléolithique et le Mésolithique (étude monographique). Préhistoire Européenne 1, 63-66.

Péan, S., 2001. Mammoth and subsistence practices during the mid Upper Palaeolithic of Central Europe (Moravia, Czech Republic). In: Cavarretta, G., Gioia, P. Mussi, M., Palombo, M.R. (Eds.), The World of Elephants/La Terra degli Elefanti, Proceedings of the 1st International Congress, 16-20 October 2001, Rome (Italy). Consiglio Nazionale delle Ricerche, Rome, pp. 331-336.

Péan, S., Patou-Mathis, M., 2003. Taphonomy of mammoth sites. In: Reuner, W.F., De Vos, J., Mol, D. (Eds.), Advances in Mammoth Research, Proceedings of the Second International Mammoth Conference, Rotterdam (Pays-Bas), 16-20 May 1999, Deinsea 9, pp. 331-345.

Pidoplichko, I.G., 1969. Pozdnepaleoliticheskie zhilischa iz kosteï mamonta na Ukraine. Izdatel'stvo Naukova Dumka, Kiev (in Russian).

Pidoplichko, I.G., 1976. Mezhirichskie zhilischa iz kosteï mamonta. Izdatel'stvo Naukova dumka, Kiev (in Russian).

Pidoplichko, I.G., 1998. Upper Palaeolithic dwellings of Mammoth Bones in the Ukraine. British Archaeological Reports, International Series 712, Oxford.

Popier, A., 1982. Le gisement moustérien du Champ-Grand (commune de SaintJean-Saint-Maurice), 3ème campagne de fouilles. Société Préhistorique de la Loire 22, 49-67.

Poplin, F., 1983. Essai d'ostéologie quantitative sur l'estimation du nombre d'individus. Festschrift Hermann Schwabedissen. Kölner Jahrbuch für Ur-and Frühgeschichte 16, 153-164. 1978-1979.

Rogatchev, A.N., 1957. Les sites à plusieurs couches culturelles de la région de Kostenki-Borschevo sur Don et le problème de l'évolution de la culture du Paléolithique supérieur dans la Plaine Russe. Matériaux et recherches sur l'Archéologie de l'URSS 59, 59-134. Moscou-Leningrad.

Scott, K., 1980. Two Hunting Episodes of Middle Palaeolithic Age at La Cotte de Saint-Brelade, Jersey (Channel Islands). Early Man: Some Precise Moments in the Remote Past. World Archaeology 12 (2), 137-152.

Shovkopljas, I.G., 1965. Mezinskaja stojanka. Izdatel'stvo Naukova Dumka, Kiev (in Russian).

Soressi, M., d'Errico, F., 2007. Pigments, gravures, parures: les comportements symboliques controversés des Néandertaliens. In: Vandermeersch, B., Maureille, B. (Eds.), Les Néandertaliens, biologie et culture. CTHS (Comité des travaux historiques et scientifiques), Paris, pp. 297-309.

Stringer, C., Gamble, C., 1993. In Search of the Neandertals: Solving the Puzzle of Human Origins. Thames and Hudson, New York.

Svoboda, J., Péan, S., Wojtal, P., 2005. Mammoth bone deposits and subsistence practises during Mid-Upper Palaeolithic in Central Europe: three cases from Moravia and Poland. Quaternary International 126-128, 209-221.

Valoch, K., 1984. Fouilles du site paléolithique de Vedrovice V, district de Znojmo. CasopisMoravskehoMusea Brno 69, 5-22.

Vangengeïm, E.A., 1961. O faune mlekopitajuschikh iz must'erskogo sloja stojanki Molodova I. Vystuplenie. Voprosy stratigrafii i periodizatsii paleolita. Trudy KIChP AN SSSR, T. XVIII (in russian).

Wojtal, P., Patou-Mathis, M., 2003. Middle Paleolithic faunal in Poland. In: PatouMathis, M., Bocherens, H. (Eds.), Le rôle de l'environnement dans les comportements des chasseurs-cueilleurs préhistoriques. Actes du XIVème Congrès de l'UISPP, Liège, Septembre 2001, British Archaeological Reports, International Series 1105, Oxford, pp. 83-89. 